\title{
INTEGRATED SUSTAINABILITY INDEX: THE CASE STUDY OF LITHUANIA
}

\author{
Dalia ŠTREIMIKIENĖ \\ Mykolas Romeris University, Faculty of Economics and Finance Management, \\ Ateities Str. 20, LT-80303 Vilnius, Lithuania, e-mail: daliastreimikiene@mruni.eu \\ Alvydas BALEŽENTIS \\ Mykolas Romeris University, Faculty of Politics and Management, Valakupių Str. 5, \\ LT-10101 Vilnius, Lithuania, e-mail: a.balezentis@gmail.com

$$
\text { doi:10.13165/IE-13-7-3-02 }
$$

\begin{abstract}
Sustainable development is the main aim of society development all over the world. It is also the priority policy area in the EU and Lithuania. The main mission of the State in implementing the Sustainable Development Strategy is the coordination and harmonisation of evolution of the main elements of sustainable development (environmental, economic and social spheres), provision of an opportunity for the population to actively participate in the sustainable development process and enjoy the results of the progress made through joint efforts. Measurement of the country's sustainability and progress achieved towards implementing the sustainable development targets is an important part of the sustainable development policy. Therefore, novel measures and tools are developed to aid the sustainability analysis. Multi-criteria methods can be applied in order to solve the intricate problem. Multicriteria decision making (MCDM) methods are suitable to tackle the sustainability assessment problem. In this study, we will apply two MCDM methods, namely ARAS and TOPSIS for a more robust assessment. The aim of the paper is to analyse and apply several MCDM methodologies for sustainability assessment in Lithuania and to evaluate the progress achieved in implementing sustainable development priorities in the country.
\end{abstract}

JEL classification: Q5, Q51, Q57, R11.

Keywords: sustainability assessment, Lithuania, sustainable development, strategy.

Reikšminiai žodžiai: darnumo vertinimas, Lietuva, darnus vystymasis, strategija.

\section{Introduction}

In 2001, in the part on the EU Sustainable Development Strategy (EU SDS) the Gothenburg European Council Conclusions stated for the introduction of a "mechanism to ensure that all major policy proposals include sustainability impact assessment covering their potential economic, social and environmental consequences". A number of 
suggestions for such an analysis have already been introduced. However, the problem is that there is no specific assessment tool but rather several different tools that are mostly discussed only on a theoretical level. One of them is sustainability impact assessment (SIA), which is increasingly recognised on the European level. Other concepts of sustainability assessment include integrated sustainability assessment (ISA), positional analysis (PA) and assessment for sustainability (Štreimikienè, Mikalauskienė, 2009).

The vision of sustainable development envisages Lithuania as a fully fledged and equal member of the EU, which has preserved its cultural authenticity and successfully adapted to globalisation, consistently implementing sustainable development policy, which, in turn, contributes to a healthier environment, appropriate use of natural and intellectual resources, moderate yet steady economic growth, public welfare, and social guarantees (Tahvonen, Kuuluvainen, 1993).

The main task (mission) of the State in implementing the Strategy is the coordination and harmonisation of the evolution of the main elements of sustainable development (environmental, economic and social spheres), providing for an opportunity for all social strata to actively participate in the sustainable development process and enjoy the results of the progress made through joint efforts.

Sustainability assessment is commonly viewed as one of the impact assessment process tools. Moreover, it is an integrated assessment tool in the sense that different dimensions of SD are counted. Sustainability impact assessment (in terms of policies and strategies) can be defined as "the systematic assessment of the potential or actual effects of a public intervention on the economic, social and environmental 'pillars' of sustainable development". A crucial difference from other integrated assessment tools is that SIA does not merely sum up separate economic, environmental and social assessments but rather emphasises their interconnection and interdependence.

Measurement of sustainability is an important part of the sustainable development policy. Therefore, novel measures and tools are developed to aid the sustainability analysis. Neumayer (2005) discussed the concepts of weak and strong sustainability.

Indeed, the multidimensionality associated with assessment of sustainability requires developing appropriate techniques capable of aggregating multiple indicators (Munda, 2005). Blancas et al. (2010) employed the goal programming model to assess tourism sustainability. Mirshojaeian and Kaneko (2011) utilised principal component analysis for a national-level analysis, whereas Floridi et al. (2011) followed the composite indicators framework to assess Italian regions. Shmelev (2011) did also construct composite indicators to estimate the dynamics of Russia's sustainable development. Shmelev and Rodríguez-Labajos (2009) employed the multi-criteria decision-making (MCDM) method NAIADE to assess the process of sustainable development in Austria. Analytic Hierarchy Process (AHP) is another well-known MCDM method relying on pairwise comparisons The assessment by applying these methods is based on the expert assessment of alternatives. The AHP uses the hierarchy-based structure of the task that enables decomposing the considered problem into several smaller sub-problems, each of which can be analysed independently, thus leading to a more easy solution of the overall problem. The pairwise comparison is applied for derivation of the needed data. The pairwise comparison is used for deriving weights of importance of the criteria and 
relative rankings of alternatives for each criterion. The AHP method is widely analysed, including considerable number and variety of articles written by different authors on the application of this method, its advantages and disadvantages (Saaty, 2080; Saaty 2090; Pohekar \& Ramachandran, 2004; Aras et al., 2004). According to the ARAS method, a utility function value determining the complex relative efficiency of a feasible alternative is directly proportionate to the relative effect of values and weights of the main criteria considered in assessments (Zavadskas, Turskis and Vilutiene, 2010). Data Envelopment Analysis does also enable aggregation of multiple indicators (Mavrotas and Trifillis, 2006).

Although Čiegis et al. (2009), also Čiegis and Kareivaitè (2009) analysed the dynamics of sustainability indicators in Lithuania, no integrated index has been offered in the literature. Therefore, the present study is focused on a national-level analysis, viz. sustainable development in Lithuania. Specifically, the MCDM method ARAS (Turskis, Zavadskas, 2010; Zavadskas et al., 2012) was employed for the analysis.

The aim of the paper is to analyse and apply several MCDA tools for sustainability assessment in Lithuania and to evaluate the progress achieved in implementing sustainable development priorities in the country. In order to achieve this aim, the main tasks are formulated:

- To analyse the key sustainable development indicators in Lithuania;

- To propose a framework for integrated assessment of Lithuania's sustainable development by applying MCDA tools.

- To apply several MCDAs for sustainability assessment in Lithuania;

- To discuss assessment results and policy implications.

\section{Sustainable Development Priorities in Lithuania}

For each country and its residents, the country's development is important, as it determines its social and economic situation. Each country wants more favourable development opportunities and bigger investment flows, but these opportunities are limited and not always achievable. A country's development depends on its infrastructure, revenue received, investments, development of industry, the number of tourists attracted, the population, its activity and change. In order to improve the country's development, one must analyse its level of development based on the major spheres: economic, social and environmental. Only after analysing those areas it can be determined whether a country's development is balanced and which of the areas lacks attention (Ciegis et al., 2009).

The Lithuanian national sustainable development strategy was approved by Resolution No 1160 of the Government of the Republic of Lithuania in 2003 (updated in 2009), stating that the strategy implementation reports shall be drafted every two years. The first report was compiled in 2005, the second in 2008 and the third is being prepared at the moment. The main objective of sustainable development in Lithuania is to achieve, by 2020, the development level of the EU countries of 2003, according to the indicators of economic and social development as well as to the efficiency in consumption of resources, and to stay within the EU's permissible limits, according to the environmental 
pollution indicators, while meeting the requirements of international conventions to minimise environmental pollution and input into global climate change. The implementation of the strategy is measured by sustainable development indicators (environmental quality: air and climate change, landscape and biological diversity, waste management, economic development: transport, industry, energy, agriculture, housing, tourism, social development: employment, poverty and social exclusion, public health, education and science, preservation of cultural identity, sustainable consumption and territorial development). As of 2004, national indicators on sustainable development are published in a separate section of the Statistical Yearbook of Lithuania and also on the websites of the Lithuanian Statistics and the Ministry of Environment.

In the national sustainable development strategy, the following priorities of Lithuania’s sustainable development can be presented as 11 priority targets:

1. Moderate and sustainable development of economic branches and regional economies;

2. Decreased social and economic disparities between regions and inside regions by maintaining their peculiarities;

3. Reduction of environmental impact from branches of economy (transport, industry, energy, agricultural housing sector, tourism);

4. More effective use of natural resources and waste disposal;

5. Reduction of health impact;

6. Climate change and its impact mitigation;

7. Protection of biodiversity;

8. Protection of landscape;

9. Increasing employment, decreasing poverty and social vulnerability;

10. Increasing the role of science and education;

11. Protection of Lithuania's cultural peculiarity.

Therefore, before choosing a policy measure, it is necessary to assess its economic, environmental and social impact based on strategic priorities of the country or sustainable development targets described above. The ex-ante evaluation of a policy measure's impact on sustainable development targets can be assessed by modelling the impact of a policy measure using the Global equilibrium or Partial equilibrium models. The ex-post evaluation of a policy measure's impact on sustainable development targets can be assessed by evaluating the changes of targeting indicators after implementation of policies (Štreimikienè, Mikalauskienè, 2009).

The evaluation of social, economic and environmental impacts of policies can be performed by applying the multi-criteria analysis, which allows assessment of policies based on the criteria that are sometimes contradictory. For example, the most expensive policies putting a heavy burden on the economy usually allow the largest emission reductions. Therefore, in order to compare policies according to contradictory criteria, it is necessary to sum up various impacts and to allocate different weights for specific criteria, taking into account the significance of criteria in decision-making. Several multi-criteria decision aiding tools have been created that allow conducting a simple multicriteria analysis and assess policies based on social, economic and environmental criteria (Streimikiene, Ciegis, Grundey, 2007). 
In Table 1, the example of sustainable development indicators system for Lithuania is presented based on national sustainable development targets. These indicators can be applied for monitoring the impact of policy measures on sustainable development targets. The main strategic priorities of Lithuania are development of innovations and new technologies, increase in labour productivity and economic growth and increase of competitiveness, reduction of regional disparities, increase in employment, reduction of unemployment, poverty and social development, effective use of natural resources and waste disposal. Therefore, it is possible to develop a system of indicators representing these main strategic priorities and to assess all policy measures according to their impact on these targets. The application of multi-criteria analysis would allow ranking policy measures targeting the same policy aims according to their efficiency of bringing the country to a sustainable development path. This allows not just ranking policy measures but also provides for the harmonisation of different policies targeting different sectors and aims.

The three groups of indicators, each of them defining the economic, environmental, and social dimensions of sustainability were established. Table 1 summarises these data.

Table 1. The dynamics of structural indicators employed for construction of the integrated sustainability index for Lithuania

\begin{tabular}{|c|c|c|c|c|c|c|c|}
\hline & $\begin{array}{c}\text { Desirable } \\
\text { trend }\end{array}$ & 2000 & 2005 & 2008 & 2009 & 2010 & 2011 \\
\hline \multicolumn{8}{|l|}{ Economic indicators } \\
\hline $\begin{array}{l}\text { Share of enterprises using } \\
\text { computers, \% }\end{array}$ & + & 80.2 & 91.7 & 94.8 & 96.1 & 96.9 & 98.1 \\
\hline $\begin{array}{l}\text { Labour productivity, value added } \\
\text { per working hour, LTL }\end{array}$ & + & 15.7 & 24.0 & 34.7 & 31.5 & 33.9 & 37.6 \\
\hline $\begin{array}{l}\text { Share of high technology sector } \\
\text { value added in total value added, \% }\end{array}$ & + & 17 & 15.8 & 22.4 & 16.5 & 23.0 & 23.1 \\
\hline Final energy intensity, toe/mill. LTL & - & 75.8 & 63.7 & 57.7 & 61.3 & 62.5 & 58.2 \\
\hline $\begin{array}{l}\text { Share of renewables in total energy } \\
\text { consumption, } \%\end{array}$ & + & 9.4 & 10.0 & 10.7 & 12.1 & 15.1 & 14.5 \\
\hline $\begin{array}{l}\text { Share of electricity produced from } \\
\text { renewables, } \%\end{array}$ & + & 3.0 & 3.1 & 4.3 & 4.5 & 15.8 & 23.1 \\
\hline $\begin{array}{l}\text { Share of biofuels in road transport } \\
\text { fuels, \% }\end{array}$ & + & 0 & 0.3 & 4.2 & 4.4 & 3.7 & 3.7 \\
\hline $\begin{array}{l}\text { Share of electricity produced by CHP } \\
\text { in total electricity production, } \%\end{array}$ & + & 20.7 & 24.5 & 20.8 & 20.9 & 73.6 & 68.3 \\
\hline $\begin{array}{l}\text { Area of organic farms to the utilised } \\
\text { agriculture land, \% }\end{array}$ & + & 0.14 & 2.42 & 4.77 & 5.02 & 5.55 & 5.63 \\
\hline Passenger cars older than 10 years, $\%$ & - & 92 & 90.6 & 83.7 & 84.5 & 85.4 & 85.7 \\
\hline $\begin{array}{l}\text { Persons injured in a road traffic } \\
\text { accident }\end{array}$ & - & 6960 & 8467 & 5818 & 4426 & 4230 & 3919 \\
\hline \multicolumn{8}{|l|}{ Environmental indicators } \\
\hline GHG emissions, $\mathrm{Mt}$ & - & 19.37 & 22.68 & 24.33 & 19.96 & 20.8 & 20.9 \\
\hline Total emissions, thou t & - & 445.6 & 389.7 & 338.7 & 332.0 & 391.2 & 392.3 \\
\hline Total amount of waste water, mill. $\mathrm{m}^{3}$ & - & 171.6 & 174.3 & 175.7 & 170.0 & 182.0 & 181.7 \\
\hline
\end{tabular}




\begin{tabular}{|c|c|c|c|c|c|c|c|}
\hline Municipal waste, thou $\mathrm{t}$ & - & 1085 & 1053 & 1139 & 1038 & 1033 & 974 \\
\hline $\begin{array}{l}\text { Recycling of industrial waste (paper } \\
\text { and cardboard), \% of amount } \\
\text { collected }\end{array}$ & + & 90.8 & 90.3 & 80.8 & 68.0 & 70.2 & \\
\hline Hazardous waste collected, tonnes & + & 99375 & 95936 & 113038 & 100795 & 109653 & 137479 \\
\hline $\begin{array}{l}\text { Forest land area, \% to the country } \\
\text { area }\end{array}$ & + & 30.1 & 30.8 & 32.0 & 32.8 & 32.9 & 33.1 \\
\hline $\begin{array}{l}\text { Protected area, \% to total country } \\
\text { area }\end{array}$ & + & 11.1 & 11.5 & 14.3 & 15.3 & 14.8 & 15.6 \\
\hline \multicolumn{8}{|l|}{ Social indicators } \\
\hline $\begin{array}{l}\text { Population provided with } \\
\text { centralised water supply compared } \\
\text { to the total population, } \%\end{array}$ & + & 72 & 73 & 74 & 74 & 75 & 75 \\
\hline $\begin{array}{l}\text { Population provided with } \\
\text { centralised sewage management } \\
\text { services, compared to the total } \\
\text { population, \% }\end{array}$ & + & 62 & 62 & 65 & 68 & 65 & 65 \\
\hline $\begin{array}{l}\text { Population using public municipal } \\
\text { waste management services, } \\
\text { compared to total population, } \%\end{array}$ & + & 77 & 77 & 80 & 89 & 91 & 94 \\
\hline Employment,\% & + & 58.7 & 62.6 & 64.3 & 60.1 & 57.8 & 60.3 \\
\hline Unemployment rate, $\%$ & - & 16.4 & 8.3 & 5.8 & 13.7 & 17.8 & 15.3 \\
\hline At risk of poverty rate, $\%$ & - & 21.0 & 20.5 & 20.6 & 20.2 & 20.0 & 20.0 \\
\hline S80/S50 income quintile ratio & - & 7.2 & 6.9 & 5.9 & 6.3 & 7.3 & 5.8 \\
\hline Average useful floor per capita, $\mathrm{m}^{3}$ & + & 23.0 & 23.8 & 24.9 & 25.8 & 26.5 & 26.9 \\
\hline $\begin{array}{l}\text { Person fatality injured due to } \\
\text { accidents at work }\end{array}$ & - & 66 & 118 & 79 & 49 & 50 & 48 \\
\hline $\begin{array}{l}\text { Households having a personal } \\
\text { computer, \% }\end{array}$ & + & 20.0 & 29.0 & 48.0 & 52.2 & 53.8 & 55.8 \\
\hline Households having internet access, $\%$ & + & 10.0 & 14.4 & 47.1 & 54.7 & 54.9 & 55.8 \\
\hline $\begin{array}{l}\text { Government expenditure on } \\
\text { education, compared to GDP, } \%\end{array}$ & + & 6 & 6 & 5.4 & 5.8 & 6.8 & 6.1 \\
\hline $\begin{array}{l}\text { Government expenditure on social } \\
\text { protection, compared to GDP, } \%\end{array}$ & + & 15.8 & 14.8 & 13.3 & 16.1 & 21.2 & 19.2 \\
\hline $\begin{array}{l}\text { Government expenditure on } \\
\text { research and development, } \\
\text { compared to GDP, \% }\end{array}$ & + & 0.59 & 0.67 & 0.75 & 0.79 & 0.84 & 0.80 \\
\hline $\begin{array}{l}\text { Number of university graduates, } \\
\text { thou }\end{array}$ & + & 14 & 26.7 & 29.3 & 31.2 & 30.9 & 29.5 \\
\hline $\begin{array}{l}\text { Participation rate of persons aged } \\
15-19 \text { in education, } \%\end{array}$ & + & 89.2 & 92.5 & 91.4 & 92.9 & 94.6 & 92.2 \\
\hline $\begin{array}{l}\text { Participation rate of persons aged } \\
20-24 \text { in education, } \%\end{array}$ & + & 35.8 & 45.5 & 48.7 & 48.1 & 49.0 & 49.7 \\
\hline Death per 10000 & - & 1112.1 & 1282.8 & 1305.3 & 1258.6 & 1281.5 & 1354.3 \\
\hline Infant deaths per 1000 lives & - & 8.5 & 6.9 & 5.0 & 5.0 & 4.3 & 4.2 \\
\hline Human development index & + & 0.749 & 0.793 & 0.800 & 0.802 & 0.805 & 0.810 \\
\hline
\end{tabular}

Source: Lithuanian Department of Statistics 
The sustainability assessment of policies can be performed on micro and macro levels. The indicators presented in Table 1 can be applied for this purpose. The development of integrated indicators constructed from the set of indicators presented in Table 1 above can be applied for sustainability assessment of policies and for monitoring the progress achieved towards sustainable development. In the following chapters, the principles for the development of integrated indicators will be presented following the example of application of integrated indicators for monitoring the national sustainable development strategy.

Integrated sustainability assessment indicators are developed for monitoring the success of implementation of the sustainable development strategy and for the sustainability assessment of policies and measures seeking to reflect the main issues of sustainable development set in the national sustainable development strategy. Such indicators, constructed from a wide range of specific structural social, economic and environmental indicators aim to evaluate important features of investigated social, economic and environmental issues addressed in the national sustainable development strategy and at the same time they show how the changes of the structural indicators influence the dynamics of the integrated indicator.

\section{The ARAS Method}

This section describes the Additive Ratio Assessment (ARAS) method, as reported by Zavadskas et al (2012). In the first stage, a multiple criteria decision making matrix, $X$, is formed. The matrix consists of $m$ rows representing the respective alternatives and $n$ columns identifying certain criteria, so that $X=\left[x_{i j}\right]_{m \times n}$, where $i$ denotes the $i$-th alternative $(i=1,2, \ldots, m), j$ stands for the $j$-th criterion $(j=1,2, \ldots, n)$. In our case, we treated different time periods as alternatives and sustainability indicators as criteria. It is worth noting that $x_{0 j}$ is the $j$-th attribute (criterion) of the ideal solution for $j=1,2, \ldots, n$. Indeed, the values of the ideal solution can be defined either 1) by putting in the pre-known optimal values of a certain phenomenon, or 2 ) by selecting the maxima for benefit criteria (minima for cost criteria):

$$
\begin{aligned}
& x_{0 j}=\max _{i} x_{i j}, \forall j \in B ; \\
& x_{0 j}=\min _{i} x_{i j}, \forall j \in C ;
\end{aligned}
$$

with $B$ and $C$ being the sets of benefit and cost criteria, respectively. The ideal alternative, $x_{0}$, thus becomes a yardstick for sustainability measurement.

The second stage of evaluation encompasses normalization of the matrix $X$. Turskis and Zvadskas (2010) employed total ratios for the latter purpose. In this study, we employ vector normalisation as the square root of the sum of squares of each alternative per criterion. As a result, a normalised decision making matrix $\bar{X}$ is established, with its elements, $\bar{x}_{i j}$, computed as follows: 


$$
\begin{aligned}
& \bar{x}_{i j}=\frac{x_{i j}}{\left(\sum_{i=0}^{m} x_{i j}^{2}\right)^{1 / 2}}, \forall j \in B ; \\
& \bar{x}_{i j}=\frac{1 / x_{i j}}{\left(\sum_{i=0}^{m} 1 / x_{i j}^{2}\right)^{1 / 2}}, \forall j \in C .
\end{aligned}
$$

Consequently, the responses of each alternative on objectives are transformed into dimensionless numbers which are bounded to the closed interval $[0,1]$ and thus suitable for multiple criteria evaluation. In addition, each criterion can be assigned with a significance coefficient, $w_{j}$, such that $\sum_{j} w_{j}=1$. Thus, the normalized matrix, $\bar{X}$, is weighed by multiplying each element therein by the respective coefficient of significance:

$$
\hat{x}_{i j}=w_{j} \bar{x}_{i j}, \forall i \in[0,1, \ldots, m] \text {, }
$$

where $\hat{x}_{i j}$ is the weighted normalised value of the $j$-th criterion for the $i$-th alternative. In the last stage the values of utility function are estimated for each of alternatives:

$$
S_{i}=\sum_{j=1}^{n} \hat{x}_{i j}, \forall i \in[0,1, \ldots, m] .
$$

As the ideal solution has been defined in the first stage, it is possible to compare the utility of each remaining alternative with that of the ideal solution by computing the following index:

$$
K_{i}=\frac{S_{i}}{S_{0}}, \forall i \in[1,2, \ldots, m],
$$

where $K_{i}$ is the relative utility index of the $i$-th alternative. It is obvious that the values of $K_{i}$ range between 0 and 1 . The best alternative is therefore chosen by maximizing $K_{i}$. Note that time periods are considered as alternatives in case of sustainability assessment.

\section{The TOPSIS Method}

The algorithm of the TOPSIS method is presented according to Hwang and Yoon (1981) and Antuchevičienè et al. (2010). The TOPSIS method will use the vector-normalised values:

$$
x_{i j}^{*}=w_{j} \frac{x_{i j}}{\left(\sum_{i=1}^{m} x_{i j}^{2}\right)^{1 / 2}},
$$

Firstly, the positive-ideal and the negative-ideal solutions, denoted respectively as $A^{*}$ and $A^{-}$, are identified as follows: 


$$
\begin{aligned}
& A^{*}=\left\{\left(\max _{i} v_{i j} \mid j \in I\right),\left(\min _{i} v_{i j} \mid j \in I^{\prime}\right), i=1,2, \cdots, m\right\}=\left\{v_{1}^{*}, v_{2}^{*}, \cdots, v_{m}^{*}\right\}, \\
& A^{-}=\left\{\left(\min _{i} v_{i j} \mid j \in I\right),\left(\max _{i} v_{i j} \mid j \in I^{\prime}\right), i=1,2, \cdots, m\right\}=\left\{v_{1}^{-}, v_{2}^{-}, \cdots, v_{m}^{-}\right\},
\end{aligned}
$$

where $I=\{j=1,2, \cdots, n\}$ and $I^{\prime}=\{j=1,2, \cdots, n\}$ are sets of benefit and cost criteria, respectively. The $n$-dimensional Euclidean distance then measures the distances of each alternative from the positive-ideal solution and the negative-ideal solution:

$$
\begin{aligned}
& S_{i}^{*}=\sqrt{\sum_{j=1}^{n}\left(v_{i j}-v_{j}^{*}\right)^{2}}, \text { for } i=1,2, \cdots, m, \\
& S_{i}^{-}=\sqrt{\sum_{j=1}^{n}\left(v_{i j}-v_{j}^{-}\right)^{2}}, \text { for } i=1,2, \cdots, m,
\end{aligned}
$$

with $v_{j}^{*}$ and $v_{j}^{-}$being obtained from Eqs. 5 and 6, respectively. Finally, the relative similarity to the positive-ideal solution is calculated (proximity to positive and remoteness to negative values):

$$
C_{i}=\frac{S_{j}^{-}}{S_{j}^{*}+S_{j}^{-}},
$$

where $C_{i} \in[0 ; 1]$ with $i=1,2, \cdots, m$. The best alternative can therefore be ranked in the descending order of $C_{i}$. These values can also be considered as the partial indices of sustainability describing developments in

\section{Aggregation of the Partial Sustainability Indices}

The ARAS and TOPSIS methods were employed for each indicator group, namely economic, social, and environmental. As a result, each time period analysed is attributed with three indices, $K_{i}^{\text {economic }}, K_{i}^{\text {social }}$, and $K_{i}^{\text {environmental }}$, associated with the respective indicator groups, i. e. sustainability dimensions. Given that these indices are bounded to the interval $[0,1]$, they are comparable without any further normalisation. The integrated sustainability index is then obtained as follows:

$$
K_{i}^{*}=\sum_{d} w_{d} K_{i}^{d}
$$

here $d$ denotes the respective dimension of sustainability, viz. $d=\{$ economic, social, environmental $\}$, and $w_{d}$ represents the weight of a certain dimension in the integrated index such that $\sum w_{d}=1$. One can thus analyse the sensitivity of the integrated sustainability index by manipulating the values of the weight vector. 


\section{Discussion of Results}

The ARAS method was employed for the three groups of indicators identifying the respective dimensions of sustainability. Within each group, equal weights were utilised, which virtually implied that no specific weight vectors were used. The resulting partial sustainability indices are presented in Fig. 1. As one can note, it was the economic development that featured both the steepest increase and proximity to the ideal alternative (time period).

Figure 1. Dynamics of partial indices comprising the integrated sustainability index based on TOPSIS method according to holistic approach, 2000-2011

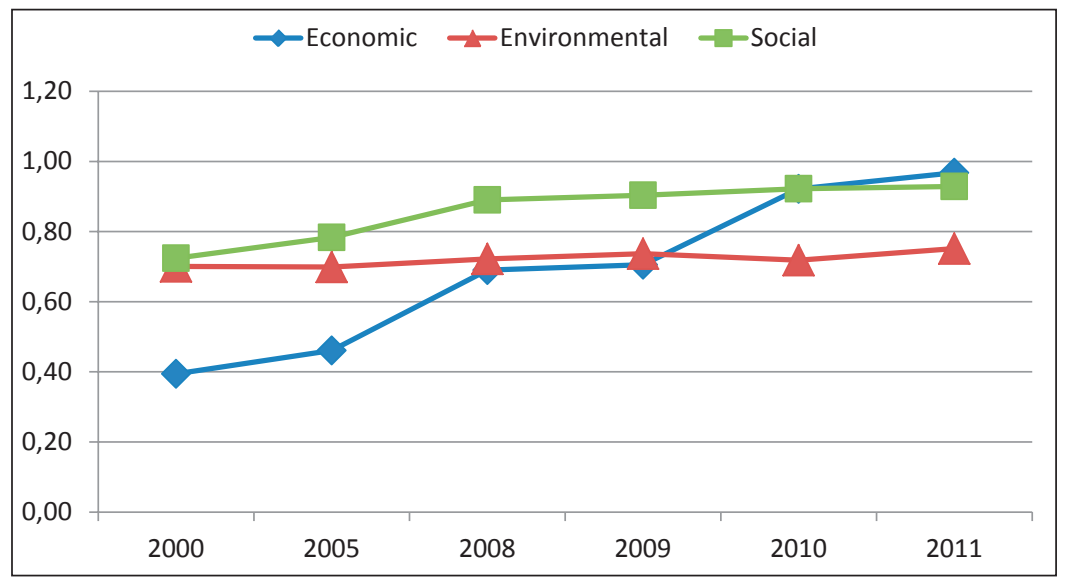

The social dimension exhibited less intensive growth and remained the second in terms of proximity to the ideal observation. The environmental dimension was not associated with any significant changes. Ineffective policy measures can be one of the main reasons for flat development trends of environmental indices during 2000-2011. Though there were several concerns about negative trends in the development of social indicators, one can notice that the trends of the main social indicators were positive during that period.

The integrated sustainability index was estimated in the spirit of Eq. 6. Specifically, four approaches were maintained. The holistic approach attributed equal weights to all of the three dimensions of sustainability. The economic, environmental, and social approaches place the highest significance (i. e. weight of 0.5 ) on the economic, environmental, and social partial indices, respectively, whereas the weights of 0.25 were assigned for the remaining dimensions. Fig. 2 exhibits the dynamics of the integrated sustainability indices. 
Figure 2. Dynamics of integrated sustainability index based on ARAS method according to three scenarios, 2000-2011.

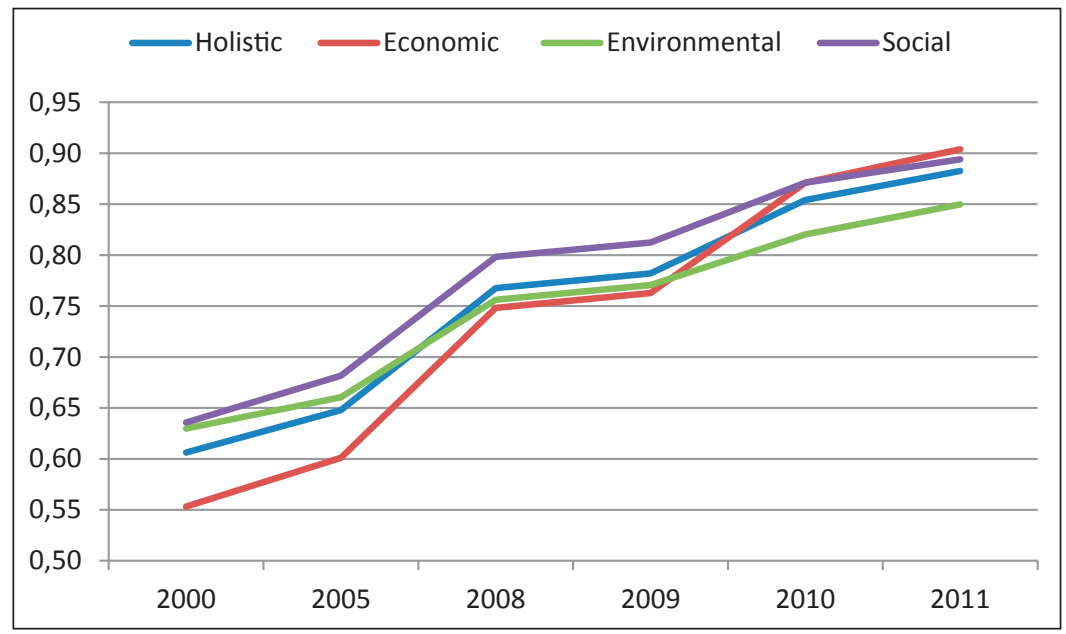

As one can see from the results provided in Figure 2, the trend of integrated sustainability assessment index developed by using the MCDA TOPSIS method was positive during 2000-2010, showing positive results in the achievement of sustainable development targets in Lithuania. Only the global economic crisis of 2008 had some negative impact on the steady growth of the integrated sustainability index in Lithuania. The integrated sustainability indices were virtually invariant to changes in weights. Indeed, partial indices of both social and environmental dimensions were peculiar with rather low variation and thus a meagre contribution to the integrated index. As a result, the economic dimension played its decisive role in the dynamics of the integrated sustainability index.

The similar integrated sustainability assessment index was developed by applying the ARAS method for sensitivity analysis of the results. Using the ARAS method, each time period was compared to the hypothetic positive-ideal one, whereas using the TOPSIS method, each period was compared to both positive- and negative-ideal ones. Therefore, sustainability progress was measured with respect to the worst and the best periods. Also, as in the case of MCDA TOPSIS, several scenarios of sustainability assessment were developed: holistic, economic, environmental and social scenarios.

The holistic approach attributing equal weights to all of the three dimensions of sustainability is presented in Figure 3. The economic, environmental, and social approaches place the highest significance (i.e. weight of 0.5 ) on the economic, environmental, and social partial indices, respectively, whereas the weights of 0.25 were assigned for the remaining dimensions. Fig. 4 exhibits the dynamics of the integrated sustainability assessment index based on ARAS method according to three scenarios. 
Figure 3. Dynamics of indices comprising the integrated sustainability index based on TOPSIS method according to holistic approach, 2000-2011

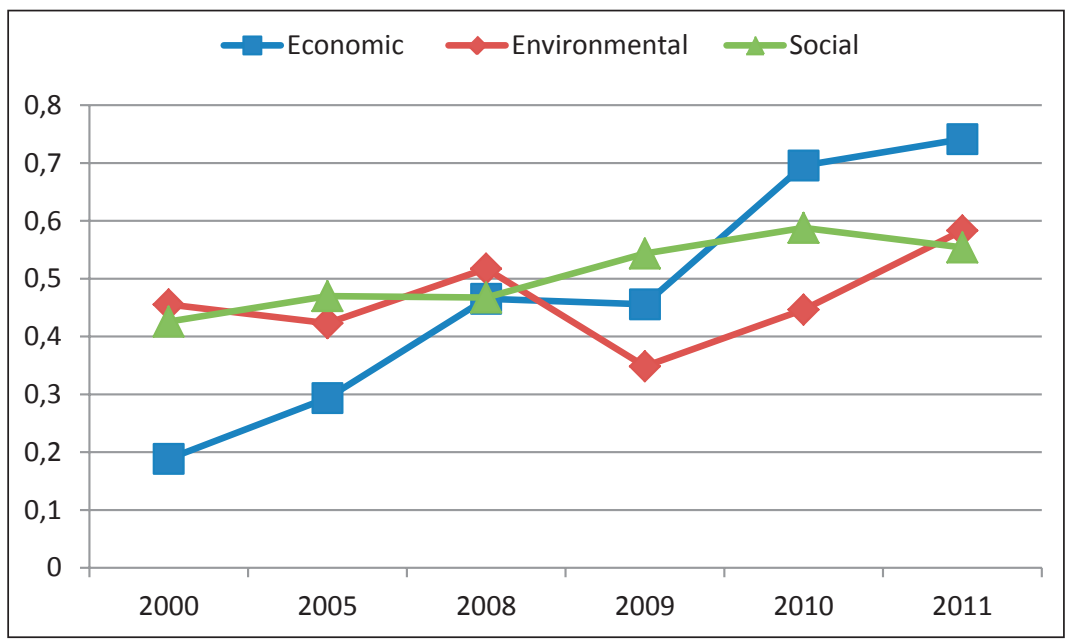

Figure 4. Dynamics of integrated sustainability index based on TOPSIS method according to three scenarios, 2000-2011

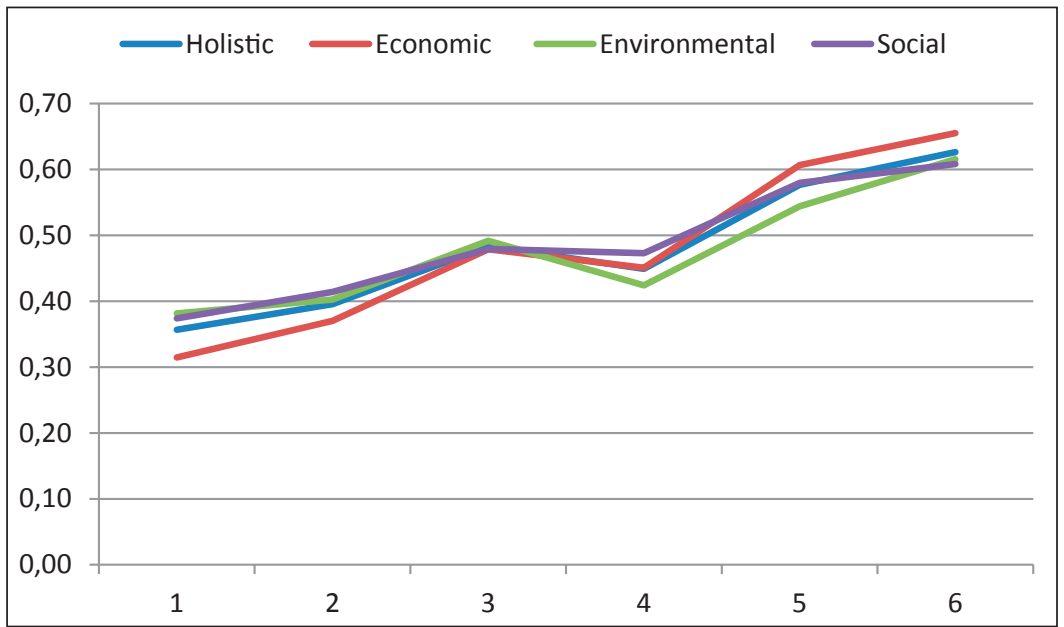

As one can see from the results provided in Figure 3, the TOPSIS method provided even for negative results in terms of development of environmental indices during the global economic crisis in 2008-2009. Other indices comprising integrated sustainability assessment index for Lithuania provided very similar results, as in the case of application 
of the ARAS method: social and economic indices were increasing and only at the time of the economic crisis this increase was at slower pace. The results presented in Figure 4 show that there are no significant differences in integrated sustainability index development for Lithuania in 2000-2010 according to different scenarios and the changes in the criteria weights according to a specific scenario do not affect the results.

\section{Conclusions}

1. Lithuania's integrated sustainability assessment index was developed by applying several MCDAs: the ARAS and the TOPSIS method. Social, economic and environmental indicators representing priority targets of the Lithuanian national sustainable development strategy were selected from the list of sustainable development indicators for the development of an integrated index for Lithuania's sustainability assessment. The results of both methods showed positive trends in sustainability assessment of Lithuania during 2000-2010.

2. A similar integrated sustainability assessment index was developed by applying two MCDAs. Using the ARAS method, each time period was compared to the hypothetic positive-ideal one, whereas using the TOPSIS method, each period was compared to both positive- and negative-ideal ones. Therefore, the progress in sustainability was measured with respect to the worst and the best periods. Several scenarios of sustainability assessment were developed for both indices: holistic, economic, environmental and social scenarios.

3. Only the global economic crisis of 2008 had some negative impact on the steady growth of the integrated sustainability index in Lithuania. The integrated sustainability indices were virtually invariant to changes in weights. Indeed, partial indices of both social and environmental dimensions were peculiar with rather low variation and thus a meagre contribution to the integrated index. As a result, economic dimension played its decisive role in the dynamics of the integrated sustainability index. Social dimension exhibited less intensive growth and remained the second in terms of proximity to the ideal observation. The environmental dimension was associated with no significant changes during the period under investigation and the ineffective policy measures could be one of the main reasons for flat development trends of environmental indices during 2000-2011.

\section{References}

1. Antuchevičienè, J., Zavadskas, E. K., Zakarevičius, A. Multiple criteria construction management decisions considering relations between criteria, Technol. Econ. Dev. Econ. 16 (2010) 109-125.

2. Blancas, F. J., Caballero, R., González, M., Lozano-Oyola, M., and Pérez, F. (2010). Goal programming synthetic indicators: An application for sustainable tourism in Andalusian coastal counties. Ecological Economics, 69(11), 2158-2172. 
3. Ciegis, R., Ramanauskiene, J., and Startiene, G. "Theoretical reasoning of the use of indicators and indices for sustainable development assessment." Inzinerine Ekonomika (Engineering Economics) 3 (2009): 33-40.

4. Čiegis, R., Kareivaite, R. The Assessment of Sustainable Development: Sustainability Tendencies in Lithuania (2000-2008) / Socialiniai tyrimai : mokslo darbai. 2009, No. 2(16). p. 5-13.

5. Floridi, M., Pagni, S., Falorni, S., \& Luzzati, T. (2011). An exercise in composite indicators construction: Assessing the sustainability of Italian regions. Ecological Economics, 70(8), 1440-1447.

6. Hwang, C. L., Yoon, K. Multiple Attribute Decision Making Methods and Applications, Springer-Verlag, Berlin, 1981.

7. Mavrotas, G. and Trifillis, P. Multicriteria decision analysis with minimum information: combining DEA with MAVT, Computers \& Operations Research, 2006, vol. 33, issue 8, p. 2083-2098.

8. Mirshojaeian Hosseini, H., \& Kaneko, S. (2011). Dynamic sustainability assessment of countries at the macro level: A principal component analysis. Ecological Indicators, 11(3), 811-823.

9. Munda, G. (2005) “Measuring sustainability“: a multi-criterion framework, Environment, Development and Sustainability, Vol. 7, No. 1, pp. 117-134.

10. Neumayer, E. (2003) Weak versus Strong Sustainability: Exploring the Limits of Two Opposing Paradigms, Cheltenham, UK and Northampton, MA, USA: Edward Elgar.

11. Pohekar, S.D. and Ramachandran, M. Application of multi-criteria decision making to sustainable energy planning-A review, Renewable and Sustainable Energy Reviews, 2004, vol. 8, issue 4, p. 365-381.

12. Saaty, T. L. How to make a decision: the analytic hierarchy process, European Journal of Operations research, 1990, vol. 48, issue 1, p. 9-26.

13. Saaty, T. L. The Analytic Hierarchy Process: Planning, Priority Setting, Resource Allocation, first ed. McGraw-Hill, New York, 1980.

14. Shmelev, S. E. (2011). Dynamic sustainability assessment: The case of Russia in the period of transition (1985-2008). Ecological Economics, 70(11), 2039-2049.

15. Shmelev, S. E., \& Rodríguez-Labajos, B. (2009). Dynamic multidimensional assessment of sustainability at the macro level: The case of Austria. Ecological Economics, 68(10), 2560-2573.

16. Štreimikienè, D. and Mikalauskienè, A. (2009), "Integruotų rodikliu taikymas Nacionalines energetikos strategijos monitoringui”, Power Engineering, 2009. T.55, Nr. 3, p. 158-166.

17. Streimikiene, D, Ciegis, R. and Grundey, D. „Energy indicators for sustainable development in Baltic States", Renewable and Sustainable Energy Reviews, 2007, vol. 11, issue 5, p. 877-893.

18. Tahvonen, O. and Kuuluvainen, J. (1993), "Economic Growth, Pollution and Renewable Resources", Journal of Environmental Economics and Management. No. 24, pp. 101-118.

19. Turskis, Z., and Zavadskas, E. K. (2010): A new additive ratio assessment (ARAS) method in multicriteria decision-making. Technological and Economic Development of Economy 16(2) 159-172. 
20. Zavadskas, E. K., Sušinskas, S., Daniūnas, A., Turskis, Z. and Sivilevičius, H. Multiple criteria selection of pile-column construction technology. Journal of Civil Engineering and Management 18, No. 6 (2012): 834-842.

21. Zavadskas, E. K., Turskis, Z. and Viluitene, T. Multiple criteria analysis of foundation instalment alternatives by applying Additive Ratio Assessment (ARAS) method. Archives of Civil and Mechanical Engineering, 2010, vol. 10, issue 3, p. 123-141.

\section{INTEGRUOTAS DARNUMO VERTINIMO INDEKSAS: LIETUVOS ATVEJIS}

Santrauka. Darnus vystymasis yra prioritetinè visuomenès vystymosi kryptis pasaulyje. Tai yra Europos Sąjungos ir Lietuvos politikos prioritetinè kryptis. Pagrindinè valstybès misija yra Darnaus vystymosi strategijos igyvendinimo koordinavimas ir pagrindinių darnumo dimensiju evoliucijos harmonizavimas bei sudarymas galimybių šalies gyventojams aktyviai dalyvauti igyvendinant darnaus vystymosi procesą bei džiaugtis pažangos, pasiektos igyvendinant prioritetinius darnaus vystymosi tikslus, rezultatais. Todèl labai svarbu nuolat vykdyti darnaus vystymosi šalyje monitoringą bei vertinti šalies pasiektą darnumo lygị. Šalies darnumo arba pasiektos pažangos igyvendinant konkrečios šalies darnaus vystymosi prioritetinius tikslus vertinimas yra svarbi darnaus vystymosi politikos dedamoji. Todèl yra kuriami ir taikomi nauji darnumo matavimo ir ịvairių darnaus vystymosi dimensijų analizés metodai. Daugiakriterinès analizės metodai leidžia vienu metu ịvertinti vienas kitam prieštaraujančias darnumo dimensijas. Šiame straipsnyje darnumo vertinimui Lietuvoje pritaikyti keli daugiakriteriniai vertinimo metodai bei nustatyta šalies pasiekta pažanga, igyvendinant Lietuvos Nacionalinès darnaus vystymosi strategijos prioritetinius tikslus. Nustatyta, kad Lietuvos raida atitinka darnaus vystymosi principus bei nustatytus prioritetinius tikslus.

Dalia ŠTREIMIKIENĖ - Habil. Dr. in economics, professor of the Institute of Economics and Business, Faculty of Economics and Finance Management, Mykolas Romeris University. Scientific research areas: sustainable energy, energy policy, climate change mitigation policies, international trade and economics.

Dalia ŠTREIMIKIENĖ - Mykolo Romerio universiteto Ekonomikos ir finansų valdymo fakulteto Ekonomikos ir verslo instituto profesoré, ekonomikos mokslų habilituota daktarè. Mokslinių tyrimų sritys: darni energetika, energetikos politika, klimato kaitos švelninimo politika, tarptautine prekyba ir ekonomika.

Alvydas BALEŽENTIS - Dr. (HP), Professor, Institute of Management, Faculty of Politics and Management, Mykolas Romeris University. Research fields: innovation policy and management, rural development.

Alvydas BALAŽENTIS - Mykolo Romerio universiteto Politikos ir vadybos fakulteto Vadybos instituto profesorius, mokslų daktaras. Mokslinių tyrimų sritys: inovacijų politika ir valdymas, kaimo vystymas. 